VU MINH HIEU

NGO MINH VU

CHIJIOKE NWACHUKWU

\title{
Exploring human \\ resources, marketing and promotion activities towards the sustainable tourism development in Phu Quoc islands, Vietnam
}

Vu Minh Hieu, Ph.D.,

Van Lang University, Faculty of Business Administration, Vietnam, ORCID: 0000-0001-9525-2013.

Ngo Minh Vu, Ph.D.,

Van Lang University, Faculty of Business Administration, Vietnam, ORCID: 0000-0002-0997-4720.

Chijioke Nwachukwu, Ph.D., Universidad de las Americas Puebla,

Department of Business Administration, Mexico, ORCID: 0000-0002-7982-2810.

\section{Introduction}

Evolving trends in consumer behaviour and expectations in the tourism sector are necessitating the need to have a competent workforce and robust marketing and promotion efforts. Countries are recognising the importance of developing the capacity of tourism service providers. However, workforce and workplace considerations have received less attention in the literature relating to sustainable tourism (Baum et al., 2016). Arguably, competent tourism workforce is vital for sustainable tourism. Additionally, well-managed tourism resources can make tourists destination to be sustainable and strategically competitive. Promotional agencies are under pressure to provide relevant information because of the emergence of new competitive destinations and sophistication in the preference of tourists with respect to differing tourism products (Seetanah \& Sannassee, 2015). However, there 
are few literature on the role of tourist promotion agencies and their marketing efforts towards the development of the tourism sector. Despite substantial funds made available by the government to such agencies in their attempt to market their countries as outstanding tourists' destinations. Vietnam is endowed with natural and cultural potential for tourism development such as beautiful beaches in favour of resort relaxation, swimming and recreation, amazing bays and pristine caves/ grottoes, islands with rich ecosystems and beautiful scenery, historical sites and relics, etc. Vietnam is one of the most preferred tourists' destinations in Asia. Phu Quoc - an island (district) of Kien Giang province is located in the Gulf of Thailand and also is the largest island in Vietnam. Phu Quoc has great potentials and invaluable resources for economic development, especially for tourism development such as tropical forests, marine resources, land resources, long coastline, beautiful beaches, numerous islands, etc. $\mathrm{Vu} \&$ Nwachukwu (2019) assert that Phu Quoc tourism sector contributes positively to the employment of local residents and reduce poverty rate. In view of scanty literature on workforce and workplace considerations and tourism marketing and promotion efforts, the present study attempts to add to the few literature. As presented above, this study aims to assess the human resources, marketing and promotion efforts of tourists service providers towards the sustainable tourism development in Phu Quoc Island in Vietnam. More importantly, we shall focus on labour force structure, structure educational level of tourism human resources, the age structure of tourism human resources, destination information accessibility by tourist and Phu Quoc tourism products.

\section{Literature review}

\subsection{Labour force and human resource in the tourism sector}

Evidently, human resources is an important resource for the success of all kinds of organizations and industries. According to Kaufman (2012), human resources management impacts positively on organizational performance. This is also agreed by Tracey (2014). In terms of tourism, As Sandra (2015) points out a human factor is the key factor to reach success, competitiveness, and survival on the market because the new market values will be created from the knowledge, skills, abilities, and motivation of the human. However, past studies reported the challenges faced by the tourism industry such challenging working conditions; dirty and difficult work; low pay; seasonal employment; low status of work; absence of clear career structures; and high labour turnover (Lee et al.,

Exploring human resources, marketing and promotion activities towards 
2008; Beaumont, 2011; Butzmann \& Job, 2017; Buckley, 2012; Ruhanen, et al., 2015). These challenges hinder the ability of the tourism sector to attract and retain a competent workforce. Human resource development in tourism focuses on developing professionally-trained and educated workforce the host community and the tourists (Font et al., 2017).

As known, to gain the sustainable tourism development of all the destinations, Qiqi \& Rova (2014) states the achievement of the determined economic standards and targets must be based on the only competent human resources. Mckercher et al. (2014) opine that sustainable human resources management focuses on long term socially and economically efficient recruitment, development, retention of employees". Arguably, a high-quality workforce in tourism will drive to the creation of exceptional tourism products to satisfy the different needs of tourists. Likewise, effective human resources management can foster tourism sustainable tourism development. Additionally, training and education of employees in the tourism sector are important to achieve sustainable tourism development.

\subsection{Marketing activities in the tourism industry}

Tourism is seen as one of the largest industries worldwide (World Travel \& Tourism Council, 2018), which is formulated from various services such as accommodation, transportation, dining, recreation, and travel. They must communicate or collaborate together to provide the best services and experiences to tourists, to develop the customers' loyalty, including the tourists. Therefore, tourism is considered as a complex industry. As by the present changes of the demands of tourism consumers with more knowledgeable and perceptive judgments on the tourism services, rapid technological advances, the increased sustainable requirements and development, the fierce market competition, etc. have altered the way and businesses are executed in the tourism sector for achieving the long-term existence and effectiveness of tourism services (Tsiotsou \& Ratten, 2010), (Vargo \& Lusch, 2004). As a consequence, on the management side, tourism enterprises and destinations must integrate marketing principles and be more market-oriented (Tsiotsou, 2010; Tsiotsou \& Vlachopoulou, 2011) and the practical strategic marketing programs are existing and adopted as a must for contemporary tourism services enterprises in order to respond to current challenges, to achieve and increase competitive advantage and the effectiveness. In the study of Seetanah \& Sannassee (2015) tourism marketing and promotion efforts in terms of attendance in road shows, marketing, publicity, and brand name among others focus on sharing information about a destination and its 
attractions. Policies for promotion and marketing in tourism are affected by downward pressure on public funding, very competitive global tourism market, new governance arrangements, and developments in social media platforms (OECD, 2017). In the tourism industry, strategic marketing becomes crucial from both theoretical and practical views. Varadarajan (2010) states a marketing strategy is a set of specific ideas and actions outlining and guiding an enterprise's decisions on managing in the most effective manner its marketing mix and sustain competitive advantage. Strategic marketing decisions encompass resource commitments and trade-offs, complement other strategic decisions and are made at the higher management level. Additionally, he also defines strategic marketing as "an organization's integrated pattern of decisions that specify its crucial choices concerning products, markets, marketing activities and marketing resources in the creation, communication and/or delivery of products that offer value to customers in exchanges with the organization and thereby enables the organization to achieve specific objectives". Cravens \& Piercy (2009) points out market-driven strategies should become the starting point of any business According to Rodoula \& Ronald (2012), a marketing strategy should not only be flexible to adapt with changes in consumers' needs, desires and preferences but be able to identify new market segments and target them successfully as well which is to gain superior business performance and sustainable competitive advantage, etc. To attract more tourists, destinations must run experiential marketing with the differentiation in their products/services from other competing destinations and provide sustainable competitive advantage (Prahalad \& Ramaswamy, 2004) because the past studies suggest that tourism marketing and promotion enhance tourist arrivals (Naude \& Saayman, 2004; Mazanec, 2005; Fallon \& Schofield, 2006; Scott et al., 2009; Correia \& Kozak, 2010).

\section{Methodology}

The qualitative and quantitative methods have been used in this study with the triangulated manner through the research tools and techniques like desk study, field observation, questionnaire survey and interviews and expert consultation as following details:

1. Field observations: the field observations has been carried out from June 2019 to September 2019 in different parts/ areas in Phu Quoc.

2. The expert consultation: the 12 experts include 6 as researchers or lecturers in the discipline of tourism development, destination management, human resources management and/or sustainable tourism development at universities

\footnotetext{
Exploring human resources, marketing and promotion activities towards the sustainable tourism development in Phu 
or institutes, 3 as senior managers or business owners who have over 7 year operation of their tourism businesses in Phu Quoc from the businesses and 3 from the local authorities as government officers in Phu Quoc Department of Tourism and Phu Quoc authorities.

3. Semi-structured interviews: the interviews have been conducted in December 2019 with 20 local residents in 10 towns/wards in five (5) 30 minute interviews (including the business owners of which are local residents), 6 local government officers in two (2) 45 minute interviews, 10 tourists in four 20 minute interviews aiming on the debate on hidden problems of sustainable tourism development in Phu Quoc which are not revealed in the questionnaires.

4. The questionnaire survey: the survey was conducted with 530 tourists, of whom 320 were domestic tourists and 210 were international tourists, 150 enterprises, 230 local residents as follows.

5. The local resident surveys were done in November 2019 under the simple random combined with Quota sampling techniques with the 230 local persons living in the community for at least 4 years, to have a full and enough understanding of the tourism in Phu Quoc to have a fully-zoned coverage of tourism problems in Phu Quoc.

6. The tourist surveys have been done with 530 tourists in equality of their manners by the simple random sampling technique is applied and done under 3 modes as from five (5) travel and tourist companies; from directly contact (at departure halls of Phu Quoc international airport and the ferries) and through Google Doc from October 2019 to middle of December 2019. It is noted that, with the international tourists, the survey is done in English language only.

7. The business survey were conducted in December 2019 with 150 tourismrelated businesses in which are 41 for accommodation services, 28 for travel services, 65 for gastronomy/foodstuff; 7 for entertainment providers and 9 for other in the $4^{\text {th }}$ quarterly meeting organized by related local authorities, from emails sent to the enterprises.

Before conducting surveys in the broad scale, pilot tests have been taken place with 4 officers in local authorities, 10 tourists including 5 domestic and 5 international, 10 with residents and 6 with entrepreneurs/managers from 2 of hotel businesses, 2 of food catering services, and 2 of craft villages to validate the data collection techniques, check comprehensibility and clarity of the questionnaire. To present the findings, the statistical technique of the analysis is used by using descriptive statistics with frequency tables, pie diagrams and bar graphs. 


\section{Results and discussion}

\subsection{Overview of the research setting}

Phu Quoc island district of Phu Quoc Province is the biggest island in Vietnam with a total area is of $589.23 \mathrm{~km}^{2}$ with 26,844 households. The present (2019) population of Phu Quoc is 146,028 persons. In 2016, the island GDP per capita was USD 5,469 (Phu Quoc department of Statistics, 2007). Phu Quoc has a very strategic position in national security and defence. Additionally, about 70 percentage of the island is covered with forests. The average temperature is from 200C to 250C with less natural calamity and floods. All of the islands in the Phu Quoc archipelago have relatively stable geological foundations, rich vegetation and high forest coverage of 64.15\%. In 2006, Phu Quoc coastal areas and islands including Phu Quoc have been recognized by UNESCO as the World Biosphere Reserve. This impacts strongly on Phu Quoc tourism development. In term of the tourism development, during the last five years, the tourists arriving in Phu Quoc has developed annually as shown in table 1 . The international visitors are rising due to more direct flights to countries as Sweden, Sweden, Russia, Korea, Singapore, Thailand, Cambodia, China, Malaysia, etc. and many more ferries transporting passengers in and out of the above routes. Additionally, there will soon be more international passenger ports in operation, contributing to increasing the number of international tourists arriving by sea. Furthermore, as for the investment endeavour, there are currently 304 projects registered to invest in Phu Quoc, with the registered investment capital of VND 361,054 billion in which there are 215 tourism development projects, 23 residential and urban projects, 8 agricultural projects, 8 public service projects, and 8 projects to lease forest environment, etc. In addition, Phu Quoc has 31 FDI projects with a total investment of USD 293 million (Phong, 2019).

Table 1. Tourists arriving in Phu Quoc

\begin{tabular}{l|c|c|c|c|c}
\hline & $\mathbf{2 0 1 5}$ & $\mathbf{2 0 1 6}$ & $\mathbf{2 0 1 7}$ & $\mathbf{2 0 1 8}$ & $\mathbf{2 0 1 9}$ \\
\hline Total & 850,000 & $1,450,000$ & $1,959,905$ & $2,550,000$ & $2,850,000$ \\
\hline International tourists & 163,000 & 210,132 & 361,452 & 637,500 & 810,000 \\
\hline Domestic tourists & 687,000 & $1,239,868$ & $1,598,453$ & $1,912,500$ & $2,040,000$ \\
\hline
\end{tabular}

Source: Phu Quoc Department of Statistics (2019)

Exploring human resources, marketing and promotion activities towards the sustainable tourism development in Phu 


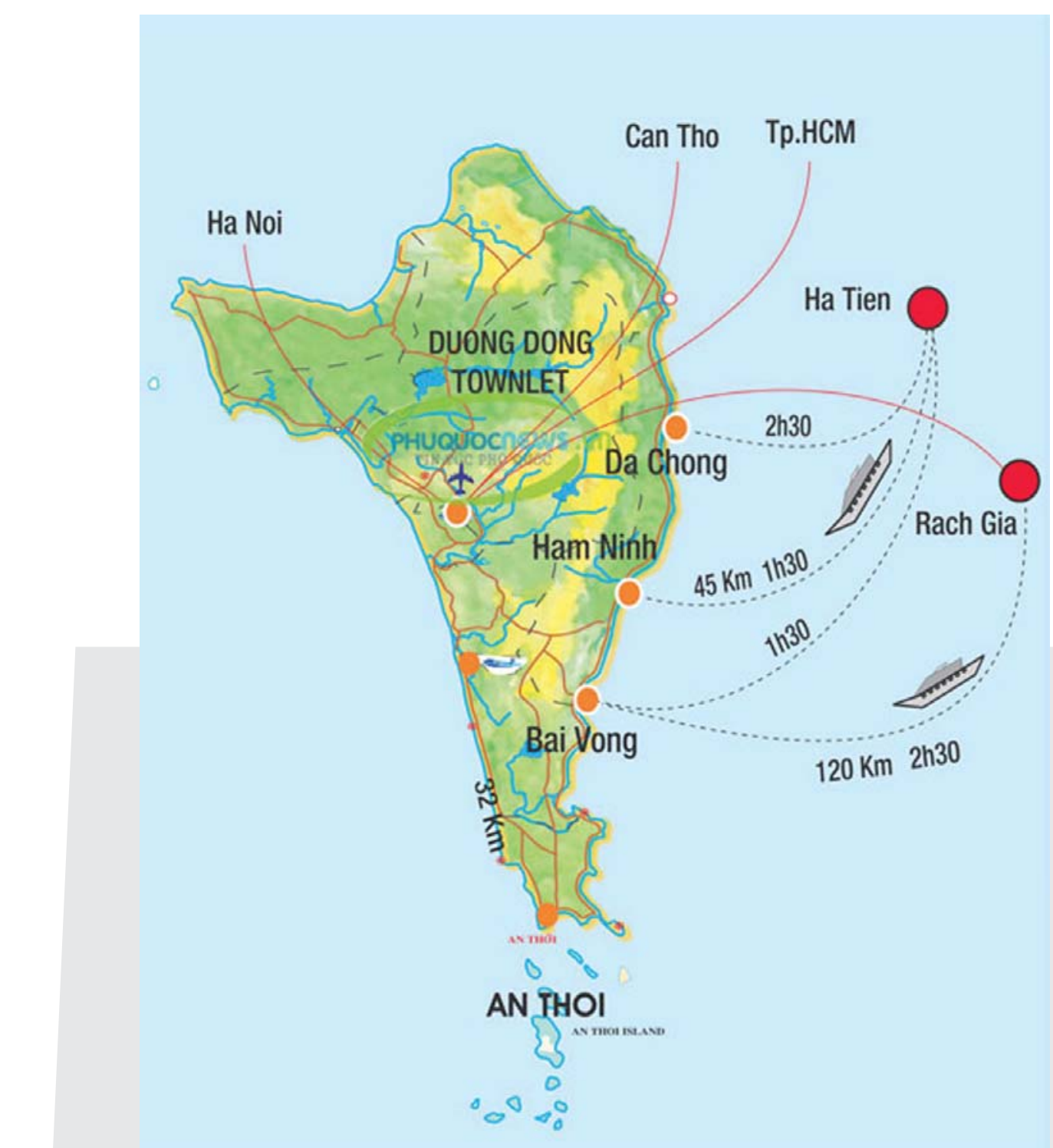

Figure 1. The distance from Phu Quoc to the surroundings

Source: http://phuquocnews.vn/ban-do-phu-quoc

\subsection{Human resources and its management}

Table 1 shows the labour force structure of Phu Quoc as reported by Phu Quoc Department of Statistics with the employed labourers increase annually. As of 
$2019,101,689$ of employed labourers in working-age accounted for $69.6 \%$ of the total population of the island. The continuous increase will happen in the coming years. In 2019, the number of labourers was 70,705 persons, accounting for $48,42 \%$ of the total population. Additionally, it is noted that the unemployment rate is not high (less than 5\%). The unemployment rate experienced a steady decline over the years.

Table 2. Labour force structure of Phu Quoc

\begin{tabular}{l|c|c|c|c|c}
\hline & $\mathbf{2 0 1 5}$ & $\mathbf{2 0 1 6}$ & $\mathbf{2 0 1 7}$ & $\mathbf{2 0 1 8}$ & $\mathbf{2 0 1 9}$ \\
\hline Quantity of laborers working in Phu Quoc & 43,939 & 51,627 & 53,588 & 66,455 & 70,705 \\
\hline Employed labourers in working age & 69,633 & 81,553 & 84,565 & 92,765 & 101,689 \\
\hline Rate (\%) & 68.38 & 68.32 & 68.33 & $68.4 \%$ & $69.6 \%$ \\
\hline Unemployment rate (\%) & 3.10 & 2.57 & 2.35 & 2.31 & 2.25 \\
\hline
\end{tabular}

Source: Phu Quoc Department of Statistics (2019)

In the context of Phu Quoc, there is only one school named Phu Quoc Vietnam - Korea vocational school that provides some vocational and short courses on tourism and hospitality management. Presently, many tourism projects invested in Phu Quoc create more employment for local residents and result the attraction of the skilled employees in Phu Quoc. Likewise, foreign-invested projects in tourism have also attracted and required a number of skilled foreign workers with professional qualifications and experience in managing tourism businesses at the international level. With the rapid growth of tourism businesses, stakeholders agree that Phu Quoc is faced with the issue of incompetent human resources and the shortage of management team of tourism businesses. Also, the quality of professional human resources in tourism businesses is still limited as shown in table 3 and 4.

Table 3. Structure of the education level of tourism human resource

\begin{tabular}{l|c|c|c|c|c}
\hline & 2015 & 2016 & 2017 & 2018 & 2019 \\
\hline Post-graduate & 5 & 6 & 8 & 15 & 27 \\
\hline University graduate & 295 & 631 & 866 & 2300 & 3213
\end{tabular}

Exploring human resources, marketing and promotion activities towards the sustainable tourism development in Phu Quoc islands, Vietnam 


\begin{tabular}{l|c|c|c|c|c}
\hline year program graduate & 462 & 351 & 424 & 2100 & 2712 \\
\hline 2 year program graduate & 651 & 926 & 1,286 & 1869 & 2567 \\
\hline Vocational or others & 467 & 648 & 858 & 3100 & 3812 \\
\hline Without training course & 4,587 & 5,692 & 7,596 & 5400 & 7532 \\
\hline Total & 6,467 & 8,262 & 11,038 & 14,784 & 19,863 \\
\hline Rate of un-trained laborers & $71 \%$ & $69 \%$ & $69 \%$ & $37 \%$ & $38 \%$ \\
\hline
\end{tabular}

Source: Phu Quoc Department of Statistics (2019)

Table 3 shows the structure of the education level of tourism human resource in Phu Quoc. In 2019, the tourism labour force of Phu Quoc has a relatively low level of education. $0.14 \%$ are post-graduate certificate holders, $16.18 \%$ for are university graduates, $13.65 \%$ are 3 -year program college graduates, $12.92 \%$ are 2 year program college graduates and $7.77 \%$ are vocational qualification graduates. $37.92 \%$ accounts for the employees who are without any training courses. In the period 2015-2019, the proportion of trained labourers has increased marvellously, in which the growth rate of the post graduate or university graduates is high $540 \%$ and $1,089 \%$ respectively.

Table 4. The ratio of education level of tourism HR for 2015- 2019.

\begin{tabular}{l|c|c|c|c}
\hline & $\begin{array}{c}\mathbf{2 0 1 5} \\
\text { (persons) }\end{array}$ & $\begin{array}{c}\mathbf{2 0 1 9} \\
\text { (persons) }\end{array}$ & $\begin{array}{c}\mathbf{2 0 1 9 - 2 0 1 5} \\
\text { (persons) }\end{array}$ & $\begin{array}{c}\mathbf{2 0 1 9 / 2 0 1 5} \\
\mathbf{( \% )}\end{array}$ \\
\hline Post-graduate & 5 & 27 & 22 & $540 \%$ \\
\hline University graduate & 295 & 3,213 & 2,918 & $1089 \%$ \\
\hline 3 year program graduate & 462 & 2,712 & 2,250 & $587 \%$ \\
\hline 2 year program graduate & 651 & 2,567 & 1,916 & $394 \%$ \\
\hline Vocational or others & 467 & 3,812 & 3,345 & $816 \%$ \\
\hline Without training course & 4,587 & 7,532 & 2,945 & $164 \%$ \\
\hline Total & 6,467 & 19,863 & 13,396 & $307 \%$ \\
\hline Rate of un-trained labourers & $71 \%$ & $38 \%$ & $-33 \%$ & \\
\hline
\end{tabular}

Source: own study (2019) 
As the rise in the numbers of persons with educational qualifications (20192019), it suggests that Phu Quoc is trying to improve the labour force by attracting employees' with professional training and development. This initiative will enhance the service quality of tourism on the island. Additionally, most of the employees are under 30 years old (42.81\%). 29.11\% of the employees are between 30 to 50 years, employees whose age is between 51 to 55 accounted for 24.68 $\%$, and 3,41\% for over 55 years old (table 4). This is consistent with tourism characteristics which require young, dynamic and healthy workforce.

Table 5. Age structure of tourism human resource in 2017

\begin{tabular}{c|c|c}
\hline & $\mathbf{n}$ & Ratio \\
\hline Under 30 year old & 4,725 & 42.81 \\
\hline $30-50$ & 3,213 & 29.11 \\
\hline $51-55$ & 2,724 & 24.68 \\
\hline Above 55 & 376 & 3.41 \\
\hline Total & 11,038 & 100 \\
\hline Source: Phu Quoc Department of Statistics (2019)
\end{tabular}

\subsection{Tourism Marketing and Promotion in Phu Quoc island}

In the context of Phu Quoc tourism marketing and promotion, the related authorities have implemented many programs and campaigns. At the national level, the Vietnam government has issued and implemented a variety of strategic decisions and policies as decision no. 01/2007/QD-TTG dated 8 January 2007 by the Government on the approval of the master plan on tourism development of Phu Quoc island in Phu Quoc province in the period 2006-2020; the decision No. 803/QD-BVHTTDL dated 9 March 2010 of the Ministry of Culture, Sports and Tourism on the approval of the project on Development of Mekong Delta tourism to 2020; decision No. 80/2013/QD-TTG dated 27 December 2013 by the government on the promulgation of a number of mechanisms, specific policies for the development of Phu Quoc, Phu Quoc province of which under that decision, 30-day visa exemption for tourists is included to promote and attract tourists to Phu Quoc. In addition, in 2016, together with other surrounding areas in Mekong Delta, the 2016 National Tourism Year had been organized. This was

Exploring human resources, marketing and promotion activities towards the sustainable tourism development in Phu

Quoc islands, Vietnam 
a cultural, economic and social event for Vietnam tourism promotion. The event was organised to introduce the potential, strengths and tourism products of Phu Quoc, Phu Quoc and the Mekong Delta region to domestic and international tourists. In 2016 National Tourism Year, many publications and articles were published such as tourist maps, brochures, leaflets, video clips to introduce Phu Quoc cuisines, beautiful landscapes, etc. In addition to these programs, Phu Quoc organized the Miss Grand International in 2017. Those important national events contributed positively to Mekong Delta tourism and Phu Quoc tourism as well. Based on the results of our interviews, most of the businesses have launched out and implemented the promotion program and campaign for Phu Quoc destination as sale-off, discount, and gift souvenir, etc. Thus, it can be concluded that in terms of activities of tourism marketing and promotion, related government authorities and businesses are more interested in using incentive schemes, supportive programs and campaigns to promote and attract tourists and even investors. To date, Phu Quoc tourism does not have an official logo and slogan. Phu Quoc tourism Marketing is vague and tourists are not impressed. This is because of a lack of professionalism on the part of tourism operators. This is consistent with the survey results, most visitors know Phu Quoc through relatives and friends, and through the use of internet search (see figure 2).

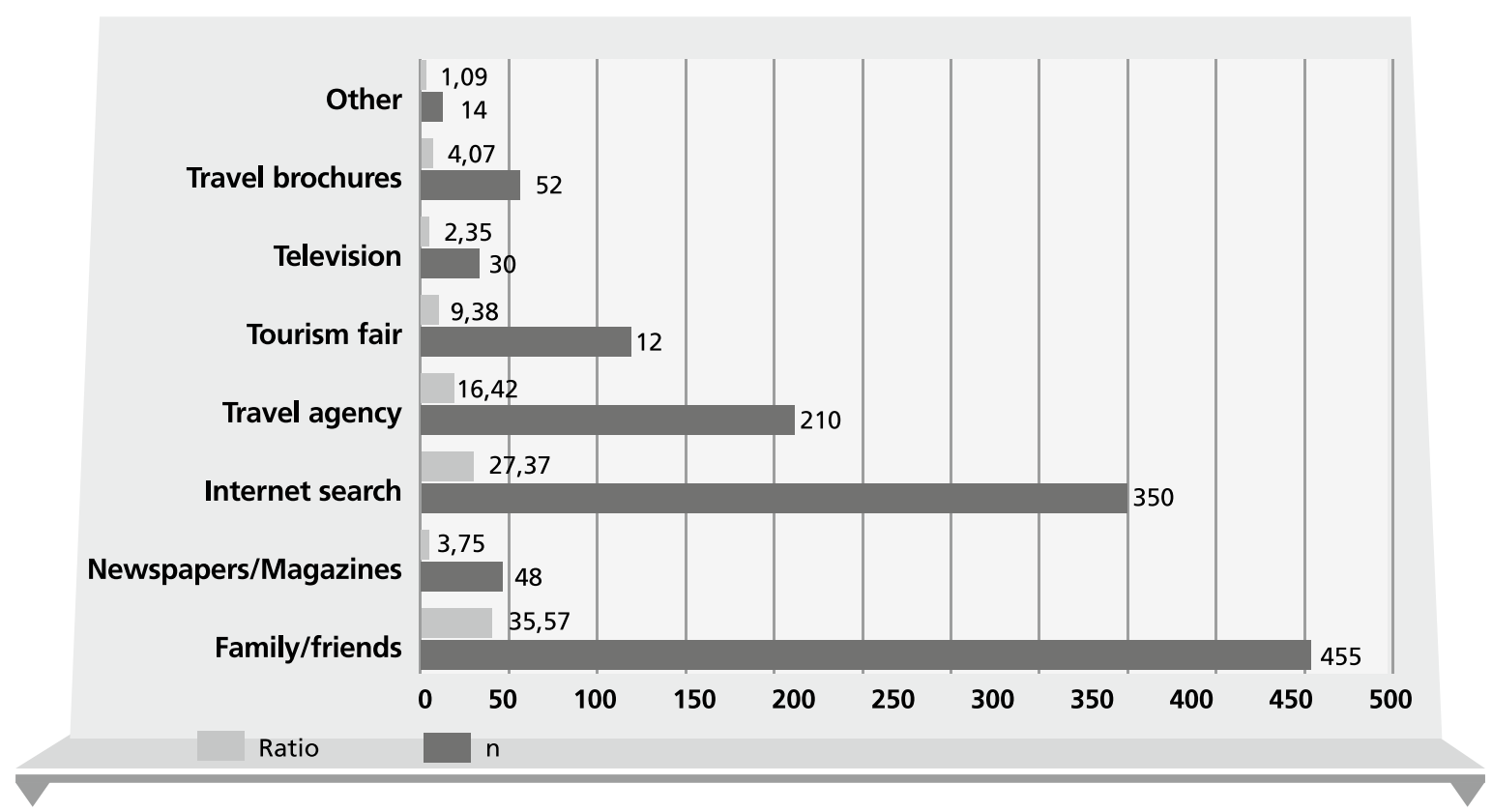

Figure 2. Destination information accessibility by tourists

Source: own study (2018) 
According to survey results and interviews with tourists, in general, the types of Phu Quoc tourism are being exploited quite sporadically and similar to other destinations, because:

1. Vietnam is a country with a long coastline with many beautiful beaches such as Phan Thiet beach, Nha Trang beach, Da Nang beach, etc. Therefore, Phu Quoc tourism products are quite similar to other destinations. This is one of the reasons for domestic tourists who do not return to Phu Quoc.

2. Domestic tourists to Phu Quoc are mainly for relaxing/ leisure, sea bathe, shopping, historical site visit (Phu Quoc prison), especially to explore the Phu Quoc's natural pristine and to see the difference between Phu Quoc and other places.

However, the survey result with stakeholders, suggest that the strong point of Phu Quoc tourism such as forest discovery tours seems to be unexploited. Forest resource has a great potential for tourism development such as ecotourism, visiting and study about tropical forests, trekking, mountain climbing, and adventure tourism. Also, recreational activities as night services are available. Furthermore, With rich tourist resources, especially with the yet-exploited ecotourism potentials, there are many types of tourism products which are available and exploitable in Phu Quoc as ecotourism, leisure travel, study tours, etc. as follows:

1. Ecotourism: ecotourism in Phu Quoc is organized into sightseeing tours, especially in uninhabited islands. There are some typical tourist sites such as Truong beach, Sao beach, Dai beach, Thom beach, Sung Hung Pagoda, Cau Temple, craft village, etc. for many tourism types like beach bathe, sea swimming; nature sightseeing tours; craft village tour; traditional festival visit; adventure exploration, etc. This tourism type is developing massively because almost all visitors joined when they made tours to Phu Quoc.

2. Leisure travel: this is a high-class and newly-formed type in Phu Quoc but its development is remarkable. Some places such as Ngan Sao Resort, La Veranda, Sasco Blue lagoon, Tropicana Island Resort, etc. with such types of honeymoon vacation, resort and spa vacation, medical treatment are typical. This type is attractive to both international and domestic tourists. They are more and more interested in the resort for their family holidays, honeymoon, conference, etc.

3. Sea sports tourism: this tourism type goes with high development potentials and it is quite new to tourists, especially with the domestic tourists who are the majority. Typical activities include coral reefs diving, fishing, etc. However, sports tourism is evaluated rather poor and unable to retain visitors.

\footnotetext{
Exploring human resources, marketing and promotion activities towards the sustainable tourism development in Phu 
4. Adventure tourism: as located in the UNESCO Biosphere Reserve, Phu Quoc is also added as an area for those who come to have sightseeing, relaxation for the purpose of research and discovery. With the types of tourism such as pristine island exploration, wildlife discovery, tropical forest adventure, etc. It is aimed at tourists such scientists, researchers, students.

\section{Conclusion}

Human resources and marketing activities play an important role in tourism development and management. However, our results reveal that Phu Quoc island lacks competent and adequate human resources in both the public and private sectors and the current marketing and promotion of the Phu Quoc tourism sector is not well developed. Tourism operators depend mainly on interpersonal relationships for doing business. Thus, they lack strategic or long-term marketing and promotional initiative. In the tourism literature, some researchers as Bagnall (1996), Riege \& Perry (2000) and Tsiotsou \& Ratten, (2010) also show the shortage of strategic marketing issues exists. The government should take charge of these strategic tasks. However, the lack of skills and strong insights usually makes them ignores these essential tasks. The study, therefore, recommend that:

- training and retraining programs should be organised for management staff of related tourism government authorities and businesses,

- training and education programs should be organised for various stakeholders in the area of professional skill and competency development, sustainable tourism development and environmental protection,

- general information channel such as website, hotline, etc. for the tourism management and promotion should be developed,

- Phu Quoc tourism brand should be developed through brand positioning, official logo design and launch-out, market share identification, etc.,

- promotion and marketing programs should be developed by advertising on different (or selected) channels, tourism trade fair participation, etc.,

- relationships with other partners, provinces/cities or inter-sectorial industries for national defence enhancement and tourism development should be established,

- destination marketing organization (DMO) should be established,

- internationally-concentrated markets should be developed,

- natural tourism products must be diversified,

- man-made tourism products should be diversified, 
- trading and tourist areas fitting tourism demand and nature conservation should be reorganised. etc.,

- tourism services such as night-life services, entertainment, etc. should be developed.

In term of the limitation of the study, the tourist survey is not implemented in the high (peak) season and most of the respondents have taken tours with travel businesses. Thus, the biases are unavoidable here to some degrees. Additionally, tourist questionnaire has been distributed in English only and tourists who do not speak English were not able to complete the survey in a manner that best reflections of their views. More of that, online survey is a limitation as known, online completion was encouraged and therefore those without access to the Internet may have been hindered in completing the survey. This study is assessed with the descriptive approach which is also considered as a limitation. Future studies should evaluate the subject using inferential statisticss. In general, the above-mentioned shortcomings and weakness can be settled by further studies and with the usage of using inferential statistics.

\section{Summary}

Exploring human resources, marketing and promotion activities towards the sustainable tourism development in Phu Quoc islands, Vietnam

Phu Quoc island of Kien Giang Province in Vietnam is endowed with resources for tourism development. The study explored the human resources, tourism marketing and promotion efforts of businesses towards the sustainable tourism development in Phu Quoc tourism. The authors used secondary and primary data to elicit information from respondents. Secondary data was collected from Kien Giang department of tourism, Statistical departments of Kien Giang and Phu Quoc. We administered questionnaires to 230 local residents, 150 businesses, and 530 tourists. Furthermore, interviews were conducted in Phu Quoc with local residents, businesses, tourists, local authorities' officers, and 12 experts. The results suggest that Phu Quoc tourism sector lack quality workforce and marketing and promotion initiative is not well developed. The study proposes recommendations to stakeholders of Phu Quoc tourism sectors and more of that, the limitation and further research is suggested.

\footnotetext{
Exploring human resources, marketing and promotion activities towards the sustainable tourism development in Phu 
Keywords: Phu Quoc, Tourism development, Tourism human resource, Tourism marketing and promotion, Vietnam.

JEL: $\quad$ M10, Z30, Z32

\section{References}

1. Baum, T., Cheung, C., Kong, H., Kralj, A., Mooney, S., Thanh, H.N.T., Ramachandran, S., Ružić, M.D., \& Siow, M.L.(2016). Sustainability and the Tourism and Hospitality Workforce: A Thematic Analysis. Sustainability, 8(8), 809; doi:10.3390/su8080809.

2. Beaumont, N. (2011). The Third criterion of ecotourism: Are ecotourism more concerned about sustainability than other tourists. Journal of Ecotourism 10, 135-148.

3. Buckley, R. (2012). Sustainable tourism: Research and reality. Annal of Tourism Research, 39(2), 528-546.

4. Butzmann, E. \& Job, H. (2017). Developing a typology of sustainable protected area tourism products. Journal of Sustainable Tourism, 25(12), 1736-1755.

5. Correia, A., \& Kozak, M. (2010). Tourism behaviour and marketing: An introduction. Journal of Hospitality Marketing \& Management, 19(3), 199-202.

6. Cravens, D.W., \& Piercy, N.F. (2009). Strategic marketing (9 ${ }^{\text {th }}$ ed.). New York, NY: McGraw Hill.

7. Fallon, G., \& Schofield, T. (2006). The dynamics of destination attribute importance. Journal of Business Research, 59(6), 709-713.

8. Font, X., Elgammal, I. \& Lamond, I. (2017) Greenhushing: The deliberate under communicating of sustainability practices by tourism businesses. Journal of Sustainable Tourism, 25(12), 1007-1023.

9. Kaufman, B. (2012). Strategic Human Resource Management Research in the United States: A Failing Grade After 30 Years?. Academy of Management Perspectives (26). 12-36.

10. Lee, C.C. \& Chang, C.P. (2008). Tourism development and economic growth: A closer look at panels. Tourism Management, 29(1), 180-192.

11. Mazanec, A. J. (2005). Tourism research in a nutshell: "The tourism knowledge map.". Tourism Review, 60(3), 6-12.

12. McKercher, B., Mak, B. \& Wong, S. (2014). Does climate change matter to the travel trade? Journal of Sustainable Tourism 22(5), 685-704.

13. Naude, W. A., \& Saayman, A. (2004). The determinants of tourist arrivals in Africa: A panel data regression analysis. Paper presented at the International Conference, Centre for the Study of African Economies, University of Oxford, Oxford, England.

14. OECD (2017). A review of the policy framework for tourism marketing and promotion. OECD Tourism Papers, 2017/01. OECD Publishing, Paris. 
15. Prahalad, C.K., \& Ramaswamy, V. (2004). Co-creation experiences: The next practice in value creation. Journal of Interactive Marketing, 18(3), 5-14.

16. Phong D. (2019). Phu Quoc will be the island city after stopping to the special economic zone (in vietnamese). Retrieved from https://www. tienphong.vn/dia-oc/phu-quoc-se-la-thanh-pho-bien-dao-sau-khi-dunglen-dac-khu-1401052.tpo.

17. Qiqi, D., \& Rova, L. (2014). Tourism development and Human Resources challenges (Gjirokastra Region). European Journal of Sustainable Development, 3(3), 211.

18. Riege, M.A. \& Perry, C. (2000). National marketing strategies in international travel and tourism. European Journal of Marketing, 34(11/12), 12901304.

19. Rodoula H.T. \& Ronald E.G. (2012). Strategic Marketing in Tourism Services. Emerald Group Publishing Ltd.

20. Ruhanen, L., Weiler, B., Moyle, B.D. \& McLennan, C.L.J. (2015). Trends and patterns in sustainable tourism research: A 25-year bibliometric analysis. Journal of Sustainable Tourism, 23(4), 517-535.

21. Sandra, H.(2015). Management of Human Resources in tourism. Paper presented at the conference Interdisciplinary Management Research XI, Croatia $180-188$

22. Scott, N., Laws, E., \& Boksberger, P. (2009). The marketing of hospitality and leisure experiences. Journal of Hospitality Marketing $\mathcal{E}$ Management, 18(2), 99-110.

23. Seetanah, B. \& Sannassee, R. V (2015). Marketing promotion financing and tourism development: the case of Mauritius. Journal of Hospitality Marketing \& Management 24. 202-215.

24. Tsiotsou, R. (2010). Delineating the effect of market orientation on service performance: A component-wise approach. The Service Industries Journal, 30(3), 357-403.

25. Tsiotsou, R., \& Ratten, V. (2010). Future research directions in tourism marketing. Marketing Intelligence \& Planning, 28(4), 533-544.

26. Tsiotsou, R., \& Vlachopoulou, M. (2011). Understanding the effects of marketing orientation and e-marketing on services performance. Marketing Intelligence \& Planning, 29(2), 141-155.

27. Tracey, J. B. (2014). A review of human resources management research: The past 10 years and implications for moving forward. International Journal of Contemporary Hospitality Management, 26(5), 679-705.

28. Varadarajan, R. (2010). Strategic marketing and marketing strategy: Domain, definition, fundamental issues and foundational premises. Journal of the Academy of Marketing Science 38, 119-140.

29. Vargo, S.L., \& Lusch, R.F. (2004). Evolving to a new dominant logic for marketing. Journal of Marketing, 68(1), 1-17.

30. Vu, H. M \& Nwachukwu, C. (2019). Perception of sustainable tourism development: insights from stakeholders in Phu Quoc island, Vietnam. International Journal of Mechanical Engineering and Technology (IJMET), 10(2), 1776-1788.

Exploring human resources, marketing and promotion activities towards 
31. World Tourism Organization - WTO. (1998) Guide for Local Authorities on Developing Sustainable Tourism. WTO: Madrid, Spain.

32. World Travel \& Tourism Council. (2018). Economic impact research. Retrieved from https://www.wttc.org/publications/2018/domestic-tourism/. 